\title{
Professional Monitoring in Achieving Teacher's Quality Learning in Industrial Revolution 4.0
}

\author{
Besse Marhawati \\ Department of Educational Administration \\ Universitas Negeri Gorontalo, Indonesia \\ bessemarhawati@ung.ac.id
}

\author{
Ansar \\ Department of Educational Administration \\ Universitas Negeri Gorontalo, Indonesia \\ ansar@ung.ac.id
}

\begin{abstract}
This article discusses professional monitoring in achieving teachers' quality learning in industrial revolution 4.0. A teacher is a critical point in education quality improvement. Therefore, teacher should achieve professional monitoring and guidance. Professional monitoring includes professional assistance and professional teachers' empowerment. Professional assistance is responsibility, which includes: assessment toward the target program which suited with the needs of the learners, improvement of the planned program, implementing changes of programs related to quality improvement of learning in class and carry out evaluation toward teaching programs carried out by teachers. Professional teacher empowerment is an effort to obtain teaching authority in accordance with professional demand of the teacher through teacher's quality improvement, critical thinking, and active participation in implementing the demands of the industrial revolution 4.0.
\end{abstract}

Keywords: professional monitoring, quality of learning, industrial revolution 4.0

\section{INTRODUCTION}

In this industrial revolution 4.0, education should be presented as a new framework to produce qualified output who possess good knowledge, attitude, and skill to strive in this digital era as everything demands people to be highly creative. Educational management in this era should implement changes in management of educational contents such as attitude, knowledge, and skill to be done in integrative ways. Modern countries like Germany have been able to adjust the education in their countries to meet the demand of industrial revolution era 4.0 and have appropriately managed the education in attitude, knowledge, and skill domains in integrated manners including the teachers' classrooms and their educational process.

According to Muhajir Effendy (The Minister of Education of Culture of the Republic of Indonesia), education need curriculum revision by adding five competencies towards the industrial revolution 4.0: (1) it is expected that students to have critical thinking skills, (2) students to have creativity and innovative skill, (3) skill and ability to communicate, (4) cooperation and collaboration, and (5) learners to have self-confident (asikbelajar.com).

A teacher is a critical point in educational reformation and a key to the success of each educational quality improvement. Regardless of the efforts, whether it is curriculum revitalization, teaching methods development, or provision of textbooks would only be meaningful when it involves teachers (National Education and Culture Department, National Planning Agency and World Bank as cited in Suhardan, 2010).

This means that learning quality is an urgent matter. Therefore, teachers should obtain constant monitoring and assistance through professional monitoring and assistance to improve quality of learning. Professional monitoring implemented through educational supervision as an effort to increase and improve the quality of teaching aimed at improving the professional behavior of teacher's performance. Sagala (2012) wrote that the core objective of teaching supervision is to assist teachers to improve their professional teaching quality.

The efforts to increase teachers' professional activity should be carried out through professional monitoring with the implementation of supervision mechanism, as supervision activity needs skill to understand academic learning activity. Professional monitoring is expected to have an impact on the increase of learning quality, learning process as learning quality is a reflection of teacher's professional ability in implementing their teaching jobs. This article describes the professional monitoring of teachers and the discussion on the professional assistance for teachers and empowerment of professional teachers.

\section{DISCUSSION}

\section{a. Professional Assistance for Teachers}

Professional assistance to develop teachers' working ability is a much-needed condition for teachers to improve their professional ability. Teachers' ability can be further developed in the field with the assistance of professional supervision of school principals to suit the needs of at the school. Supervision of this professional assistance is empowerment in the form of sustainable assistance provided for teachers to suit the demand of their job.

There are several important aspects in supervision activities namely: (1) nature is assistance and service provided by school principal for his teachers and staffs, (2) to develop teachers' quality, (3) for the professional development of teachers, and (4) to motivate teachers. Those aspects demand knowledge on the concepts and supervision approach, which supported by high performance and accountability of the supervisor. This is intended for the supervision activity to be professional service to increase teacher's competency in learning to optimize the learning output (Masaong, 2012).

Even though teachers have background knowledge, and sufficient skill and ability obtained during their preservice and in-service training, teachers often find difficulties to adjust their knowledge and the needs of 
learning in school. Development and changes, as well as new policies, need new ability to implement. Such problems demand school principal to carry out coaching towards teacher to improve the quality of teaching in school to suit the demands of the era. The era demands professional ability. Many teachers have tried to solve the difficulties by themselves. This type of problem-solving would only solve individual problems and would not bring any institutional changes.

Assistances are revealed such as technical assistance to improve learning methods, solving individual problems, enrichment or curriculum development, teaching materials mastery, worksheet development, utilization of learning source as well as textbook selection. When teachers do not obtain regular assistance, it is highly possible that there would be times when their knowledge, skill, and ability obtained during their preservice training would not be sufficient and would not be developed due to boringness, which may lead to a decline of their achievement. This would be a great loss for the efforts to increase the quality of education (Suhardan, 2010).

In carrying out supervision, a supervisor needs to fully understand the basic skill of teachers and their competencies. Those basic skills are: (1) know the foundation of the education, (2) master the teaching materials, (3) ability to manage teaching and learning program, (4) ability to manage class, (5) ability to manage teaching and learning interaction, (6) measure the students' learning outcome, (7) ability to recognize and interpret curriculum, (8) recognize function and programs of guidance and curriculum, (9) understand the principles and result of teaching, and (10) recognize and implement educational administration.

Meanwhile, teachers' competencies consist of: pedagogic competency, personal competency, social competency, and professional competency. These are important for the supervisor for the implementation of teaching and learning could be socially accountable to the community. The responsibility toward professional competency of the teachers to teach is part of the community demands toward the teaching effectiveness. Therefore, school principal's sensitivity as supervisor toward teacher's professionalism, thus, educational supervision is asked to provide special attention to improve teaching quality thus, better quality is achieved (Sagala, 2012).

The result of studies by Lipham (as cited in Sagala, 2012) related to the performance of a successful school principal is those who have a strong commitment toward the improvement of learning quality. Strong commitment describes the willingness and ability to carry out monitoring in all activities of the school personnel. For instance, in the teaching aspect, school principal could monitor the time and teaching process in class, thus, ensure the effectiveness of teaching program implementation in class. School principal who have sufficient ability to solve curriculum development problems to respond to changes. Those changes should be responded in learning objectives and school objectives, the content of the learning, method, and approach in teachings, evaluation, and other activities related to learning services. To solve all learning problems at school, teachers need assistance and guidance from school principal in the form of supervision as part of the professional responsibility of the school principal.

In relation to this professional education responsibility, Lipham further recommends four phases of teaching guidance namely: (1) assessing program objectives, where school principal needs to test whether the teaching program has met the needs of the learners, (2) planning program improvement, improvement of the planned programs by selecting the appropriate working structure, collecting information and accurate data related to the learning and utilize them to carry out improvement and development of learning program to suit the needs of the program, (3) implementing program change, carry out changes of programs by motivating the teachers to use more interactive and interesting learning strategies, motivating the staffs to provide better services to support teaching and learning activities, and motivating the school community to support the quality improvement of learning at school, and (4) evaluation of program change, implement evaluation toward the implemented changes by measuring the outcomes of learning.

\section{b. Empowerment of Professional Teachers}

Professional assistance provided by school principal as supervisor of the teachers is one of the efforts to provide changes for teachers to professionally develop, thus, they will be able to maximally implement their tasks. Teachers are able and willing to improve and increase their learners' learning ability. Considering the importance of this professional guidance for the teachers, school principal should always increase and refresh his knowledge better than his teachers, as when the principal's ability is similar or below the teachers' level, his guidance and assistance would not be meaningful. School principal as supervisor should clearly know what to be supervised and how to supervise.

Teacher empowerment is an effort to increase teachers' competency in their profession. Professional teachers' empowerment is an effort for the teacher to obtain needed teaching aptitude to suit the demand of the era. In this industrial revolution 4.0 era, teachers are demanded to be more critical and active in their jobs' implementation. Appropriate assistance for teachers would help them to carry out their tasks professionally. Empowered teachers would be sensitive to the needs of their students, and able to seek solution toward any teaching obstacles. This is due to the daily tasks of the teachers to implement learning for their learning is in sync with the objectives of education stipulated within the curriculum, and presented the teaching using appropriate methods to attain the objectives. When teachers are not empowered, the teachers would be just doing their routine, thus, it is not impossible for them to become bored, and their achievement would decrease (Suhardan, 2010).

There are several problems faced by the teachers in implementation of the 2013 curriculum especially regarding: (1) standard content, teachers are yet to understand the basic framework and the structure of the curriculum, insufficiency of time as the content are too 
broad, concept establishment is yet supported by information technology; (2) standard process, where teachers experience difficulties to develop lesson plan, implementation of scientific learning, integrated themes, constructivism, utilization of IT such as laptop and LCD; (3) standard competencies of output, difficulties in developing integrated attitude, knowledge, and skill competencies; (4) standard assessment, difficulties in developing test items and developing non-test instrument, implement process assessment as number of students within the classroom is too many. Meanwhile, the learning supervision framework model in assisting to solve teachers' problems such as implementation of group supervision, and for teachers with specific problems individual supervision model is applied (Maisyaroh, et al., 2014).

School principal has the task to ensure the success of the whole learning programs in school and teachers and students' progress. This is implemented by the principal through prominent education programs, diagnosing sustainable learning programs, discuss learning programs with teachers, and assist teachers in identifying the objectives of learning and ideas and experience on curriculum and other learning problems (Sobri, 2013).

A study by Dysvik, A \& Kuvaas, B (2012), showed that the climate of supervisor support perception positively correlates with the climate development of the employees. Therefore, the school principal in implementation of his function as supervisor to cooperate with people, either with teachers or supporting staff, to carry out learning improvement in school is in sync with the demand of the new era. Adjustments are needed during the change, such as the current industrial revolution 4.0, thus school principal assistance and professional services for teachers to meet the demand of this new are needed. For such needs, teacher's empowerment in school and in implementation of their tasks are needed.

\section{CONCLUSION}

Professional monitoring is an effort to improve and increase the quality of teachers toward the improvement of professional teachers' performance. Professional monitoring covers professional assistance toward teachers and professional teachers' empowerment. Professional assistance is professional responsibility that encompasses: assessment toward the objective of the program, which suited to the needs of the learners, improvement of the planned educational programs, carry out changes in order to increase learning quality in school, and carry out evaluation of the learning programs implemented by teachers. Empowerment of professional teachers is an effort to make teacher obtain their teaching authority that meet the professional demands through assistance and guidance of their teaching ability, critical thinking and active participation in the implementation of their tasks in this industrial revolution 4.0

\section{RECOMMENDATION}

Based on the conclusion above, it is recommended for the school principal to carry out professional monitoring for teachers to increase their teaching quality through professional assistance and teacher's empowerment to suit the demand of industrial revolution 4.0.

\section{REFERENCES}

[1] Asyik Belajar. 2018. Catatan Untuk Dunia Pendidikan di Era Revolusi Industri 4.0. Retrieved 25 July 2019, from http://asikbelajar.com.

[2] Dysvik, A, \& Kuvaas, B. 2012. Perceived Supervisor Support Climate, Perceived Investment In Employee Development Climate, and Business-Unit Performance. Human Resource Management, 51,(5), 651-664.

[3] Maisyaroh. 2014. Masalah Guru dalam Impelementasi Kurikulum 2013 dan Kerangka Model Supervisi Pengajaran. Jurnal Manajemen Pendidikan. 24, 213-220.

[4] Masaong. A.K. 2012. Supervisi Pembelajaran dan Pengembangan Kapasita Guru (Memberrdayakan Pengawas Sebagai Gurunya Guru). Bandung: Alfabeta.

[5] Sagala, Syaiful. 2012. Supervisi Pemebelajaran dalam Profesi Pendidikan. Bandung: Alfabeta.

[6] Sahertian, Piet. A. 2008. Konsep Dasar dan Teknik Supervisi Pendidikan Dalam Rangka Pengembangan Sumber Daya Manusia. Jakarta: Rineka Cipta.

[7] Sobri, A.Y. 2013. Pembinaan Profesionalisme Guru dalam Meningkatkan Kualitas Pembelajaran. Jurnal Manajemen Pendidikan, 24, 9-10.

[8] Suhardan, Dadang. 2010. Supervisi Profesional (Layanan Dalam Meningkatkan Mutu Pembelajaran di Era Otonomi Daerah). Bandung : Alfabeta.

[9] Purwanto M. N. 2018. Administrasi dan Supervisi Pendidikan. Bandung: PT Remaja Rosdakarya. 